\title{
RNA/DNA co-analysis from human saliva and semen stains--results of a third collaborative EDNAP exercise
}

Haas, Claus; Hanson, E; Anjos, M J; Banemann, R; Berti, A; Borges, E; Carracedo, A; Carvalho, M; Courts, C; De Cock, G; Dötsch, M; Flynn, S; Gomes, I; Hollard, C; Hjort, Benjamin Benn; Hoff-Olsen, P; Hríbiková, K; Lindenbergh, A; Ludes, B; Maroñas, O; McCallum, N; Moore, D; Morling, N; Niederstätter, H; Noel, F; Parson, W; Popielarz, C; Rapone, C; Roeder, A D; Ruiz, Y; Sauer, E; Schneider, Peter; Sijen, T; Court, D Syndercombe; Sviežená, B; Turanská, M; Vidaki, A; Zatkalíková, L; Ballantyne, J Published in:

Forensic science international. Genetics

DOI:

10.1016/j.fsigen.2012.10.011

Publication date:

2013

Citation for published version (APA):

Haas, C., Hanson, E., Anjos, M. J., Banemann, R., Berti, A., Borges, E., Carracedo, A., Carvalho, M., Courts, C., De Cock, G., Dötsch, M., Flynn, S., Gomes, I., Hollard, C., Hjort, B. B., Hoff-Olsen, P., Hríbiková, K.,

Lindenbergh, A., Ludes, B., ... Ballantyne, J. (2013). RNA/DNA co-analysis from human saliva and semen stains--results of a third collaborative EDNAP exercise. Forensic science international. Genetics, 7(2), $230-9$. https://doi.org/10.1016/j.fsigen.2012.10.011 


\title{
RNA/DNA co-analysis from human saliva and semen stains - Results of a third collaborative EDNAP exercise
}

\author{
C. Haas ${ }^{\mathrm{a}, *}$, E. Hanson ${ }^{\mathrm{b}}$, M.J. Anjos ${ }^{\mathrm{k}}$, R. Banemann ${ }^{\mathrm{r}}$, A. Berti ${ }^{\mathrm{n}}$, E. Borges ${ }^{\mathrm{j}}$, A. Carracedo ${ }^{\mathrm{t}}$, M. Carvalho $^{\mathrm{k}}$, \\ C. Courts ${ }^{\text {h }}$, G. De Cock $^{\mathrm{m}}$, M. Dötsch ${ }^{\mathrm{r}}$, S. Flynn ${ }^{\mathrm{u}}$, I. Gomes ${ }^{\mathrm{g}}$, C. Hollard $^{\mathrm{c}}$, B. Hjort ${ }^{\mathrm{l}}$, P. Hoff-Olsen ${ }^{\mathrm{q}}$, \\ K. Hríbiková ${ }^{\mathrm{w}}, \mathrm{A}$. Lindenbergh ${ }^{\mathrm{d}}$, B. Ludes ${ }^{\mathrm{c}}, \mathrm{O}_{\text {. Maroñas }}{ }^{\mathrm{t}}, \mathrm{N}$. McCallum ${ }^{\mathrm{u}}$, D. Moore ${ }^{\mathrm{p}}, \mathrm{N}$. Morling ${ }^{\mathrm{l}}$, \\ H. Niederstätter ${ }^{o}$, F. Noel ${ }^{\mathrm{m}}$, W. Parson ${ }^{\mathrm{o}}$, C. Popielarz ${ }^{\mathrm{j}}$, C. Rapone ${ }^{\mathrm{n}}$, A.D. Roeder ${ }^{\mathrm{s}}$, Y. Ruiz ${ }^{\mathrm{t}}$, E. Sauer $^{\mathrm{h}}$, \\ P.M. Schneider ${ }^{g}$, T. Sijen ${ }^{\text {d }}$, D. Syndercombe Court ${ }^{v}$, B. Sviežená e, M. Turanská ${ }^{\text {, }}$ A. Vidaki ${ }^{v}$, \\ L. Zatkalíkováf ${ }^{\mathrm{f}}$ J. Ballantyne ${ }^{\mathrm{b}}$
}

${ }^{a}$ Institute of Legal Medicine, University of Zurich, Switzerland

${ }^{\mathrm{b}}$ National Center for Forensic Science, University of Central Florida, Orlando, USA

${ }^{\mathrm{c}}$ Institute of Legal Medicine, University of Strasbourg, France

${ }^{\mathrm{d}}$ Netherlands Forensic Institute, The Hague, The Netherlands

${ }^{\mathrm{e}}$ Institute of Forensic Science, Department of Criminalistic Biology and Genetic Analysis, Bratislava, Slovakia

${ }^{\mathrm{f}}$ Institute of Forensic Science, Ministry of the Interior, Department of Biology and DNA Analysis, Slovenská Lupca, Slovakia

${ }^{\mathrm{g}}$ Institute of Legal Medicine, Medical Faculty, University of Cologne, Germany

${ }^{\mathrm{h}}$ Institute of Legal Medicine, University of Bonn, Germany

${ }^{\mathrm{j} I n s t i t u t ~ N a t i o n a l ~ d e ~ P o l i c e ~ S c i e n t i f i q u e, ~ L a b o r a t o i r e ~ d e ~ P o l i c e ~ S c i e n t i f i q u e ~ d e ~ L y o n, ~ F r a n c e ~}$

${ }^{\mathrm{k}}$ Forensic Genetic Service, Centre Branch, National Institute of Legal Medicine, Coimbra, Portugal

${ }^{1}$ Section of Forensic Genetics, Department of Forensic Medicine, Faculty of Health and Medical Sciences, University of Copenhagen, Denmark

${ }^{\mathrm{m}}$ National Institute for Criminalistics and Criminology, Brussels, Belgium

${ }^{\mathrm{n}}$ Reparto Investigazioni Scientifiche di Roma, Rome, Italy

${ }^{\circ}$ Institute of Legal Medicine, Innsbruck Medical University, Austria

${ }^{\mathrm{p}}$ LGC Forensics, Middlesex, UK

${ }^{\mathrm{q}}$ Department of Forensic Genetics, Norwegian Institute of Public Health, Oslo, Norway

${ }^{\mathrm{r}}$ Bundeskriminalamt, Wiesbaden, Germany

${ }^{\mathrm{s}}$ Orchid Cellmark Ltd., Abingdon, UK

${ }^{\mathrm{t}}$ Forensic Genetics Unit, Institute of Legal Medicine, University of Santiago de Compostela, Spain

${ }^{\mathrm{C}}$ Centre for Forensic Science, Department of Pure and Applied Chemistry, University of Strathclyde, Glasgow, Scotland, UK

${ }^{v}$ Academic Haematology, Blizard Institute, Barts and The London School of Medicine and Dentistry, London, UK

${ }^{\mathrm{w}}$ Comenius University, Faculty of Natural Sciences, Department of Genetics, Bratislava, Slovakia

\section{A R T I C L E I N F O}

\section{Article history:}

Received 22 April 2012

Received in revised form 27 August 2012

Accepted 12 October 2012

\section{Keywords:}

Forensic science

Body fluid identification

Saliva

Semen

EDNAP exercise

mRNA profiling

\begin{abstract}
A B S T R A C T
A third collaborative exercise on RNA/DNA co-analysis for body fluid identification and STR profiling was organized by the European DNA Profiling Group (EDNAP). Twenty saliva and semen stains, four dilution series (10-0.01 $\mu$ l saliva, 5-0.01 $\mu \mathrm{l}$ semen) and, optionally, bona fide or mock casework samples of human or non-human origin were analyzed by 20 participating laboratories using an RNA extraction or RNA/DNA coextraction method. Two novel mRNA multiplexes were used: a saliva triplex (HTN3, STATH and MUC7) and a semen pentaplex (PRM1, PRM2, PSA, SEMG1 and TGM4). The laboratories used different chemistries and instrumentation and a majority $(16 / 20)$ were able to successfully isolate and detect mRNA in dried stains. The simultaneous extraction of RNA and DNA from individual stains not only permitted a confirmation of the presence of saliva/semen (i.e. tissue/fluid source of origin), but allowed an STR profile of the stain donor to be obtained as well. The method proved to be reproducible and sensitive, with as little as $0.05 \mu l$ saliva or semen, using different analysis strategies. Additionally, we demonstrated the ability to positively identify the presence of saliva and semen, as well as obtain high quality DNA profiles, from old and compromised casework samples. The results of this collaborative exercise involving an RNA/DNA co-extraction strategy support the potential use of an mRNA based system for the identification of saliva and semen in forensic casework that is compatible with current DNA analysis methodologies.
\end{abstract}

(c) 2012 Elsevier Ireland Ltd. All rights reserved.

\footnotetext{
* Corresponding author at: Institute of Legal Medicine, Forensic Genetics, University of Zürich, Winterthurerstrasse 190,8057 Zürich, Switzerland. Tel.: +4144635 56 56; fax: +41446356858.

E-mail address: cordula.haas@irm.uzh.ch (C. Haas).
} 


\section{Introduction}

The analysis of cell-specific mRNA expression is a confirmative method for the identification of body fluids [1-24], as opposed to conventional immunological and enzymatic tests, most of which either lack specificity or cannot be used to identify all forensically relevant biological fluids. The suitability of mRNA profiling assays with forensic samples, such as old and environmentally compromised samples, has been demonstrated [25-28]. Previously, two collaborative exercises were performed by the European DNA Profiling Group (EDNAP - http://www.isfg.org/EDNAP) in order to evaluate the robustness and reproducibility of mRNA profiling for blood identification: (1) evaluation of three blood-specific markers (HBB, SPTB and PBGD) using singleplex reactions [29]; (2) evaluation of seven blood-specific markers using two multiplex systems, a 'high sensitivity' duplex (HBB, HBA) and a 'moderate sensitivity' pentaplex (ALAS2, CD3G, ANK1, PBGD and SPTB) [30]. Most laboratories, some of which had no prior experience with RNA, were able to successfully isolate and analyze RNA from the provided samples. While sensitivity varied between laboratories, the method proved to be reproducible and sensitive using different analysis strategies $[29,30]$.

A third collaborative exercise was organized by the Institute of Legal Medicine, University of Zürich, Switzerland, on behalf of EDNAP in order to test forensically suitable saliva and semen markers. In a preliminary study performed by the Florida and Zürich laboratories, various saliva and semen mRNA markers described in the literature $[3,6,8,9,13,15,18]$ as well as from unpublished data (Table 1) were evaluated in terms of sensitivity, specificity and performance with casework samples. In this study, 7 saliva and 11 semen markers were tested, of which 3 saliva and 5 semen markers were deemed most suitable for forensic use (Table 1 ). For this exercise, the following saliva and semen multiplexes were developed and provided to the participating laboratories: (1) a saliva triplex including the markers HTN3, STATH and MUC7 and (2) a semen pentaplex allowing the detection and differentiation of sperm (PRM1, PRM2) and seminal plasma (PSA, SEMG1 and TGM4), the latter of which is necessary for the identification of semen from azoospermic men. The exercise included two rounds of testing: In the original exercise (part 1), 5 laboratories encountered technical problems (reduced sensitivity, no result at all, contamination of negative controls and spectral pull-ups). As a consequence, a second exercise (part 2) was arranged in order identify the source of these problems, and potentially to obtain improved results. Each part of the exercise included the analysis of 10 mock casework samples, saliva and semen dilution series and, if available, optional extra casework samples from the participating laboratories. In addition to the provided samples analyzed by all laboratories, a set of human tissues and animal saliva samples were tested with the multiplexes by 4 laboratories to complement the specificity testing of the markers.

\section{Materials and methods}

\subsection{Samples and materials provided}

The organizing laboratory (Institute of Legal Medicine, University of Zürich, Switzerland) sent 2 sets of samples to the participating laboratories: part 1 included stains 1-10 (saliva, semen, non-saliva/semen and non-human stains) and dilution series A (5-0.01 $\mu \mathrm{l}$ semen) and B (5-0.01 $\mu$ l saliva); part 2 included stains 11-20 (saliva, semen, non-saliva/semen and nonhuman stains) and dilution series C (10-0.05 $\mu$ l saliva) and D (5$0.01 \mu \mathrm{l}$ semen). Fresh saliva samples were collected from 10 individuals for 12 stains/dilution series (different donors were used for parts 1 and 2 except for one donor who was used in both parts) and were deposited onto different carrier materials including cotton swab/pads, recycling tissue, paper and glass slides. Additionally, quarter pieces of chewed chewing gums and licked plastic spoons were provided. Semen samples from 9 individuals were used to prepare 10 stains/dilution series (different donors were used for parts 1 and 2 except for one donor who was used in both parts). The semen, which had been frozen for up to 25 years, was deposited onto different carrier materials including cotton swab/pads, white textile, toilet paper and latex gloves. In addition, blood samples (2 donors), vaginal swabs ( 1 donor) and buccal swabs from a dog and a cat were used as non-saliva/semen and non-human stains. For the dilution series, saliva and semen samples were diluted in $0.9 \% \mathrm{NaCl}$ to a final volume of $5 \mu \mathrm{l}$ per sample and placed on swabs. The laboratories

Table 1

List of evaluated mRNA markers for the identification of saliva and semen.

\begin{tabular}{llr}
\hline RNA marker & Protein & Ref. \\
\hline Saliva & Histatin 3 & 6 \\
HTN3 & Statherin & 6 \\
STATH & Mucin 7 & $*$ \\
MUC7 & Proline-rich proteins & $*$ \\
PRB1-3 & Proline-rich protein & 8 \\
PRB4 & Small proline-rich protein 2A & 13 \\
SPRR2A & Keratin 13 & 13 \\
KRT13 & & 3,6 \\
\hline Semen & Protamine 1 & 3,6 \\
PRM1 & Protamine 2 & $18,{ }^{*}$ \\
PRM2 & Transglutaminase 4 & 9,15 \\
TGM4 & Prostate Specific Antigen, Kallikrein 3 & 9,15 \\
PSA/KLK3 & Semenogelin 1 & $*$ \\
SEMG1 & SPANX family member B & $*$ \\
SPANXB & Heat Shock Transcription Factor, Y-Linked & $*$ \\
HSFY & Sperm Adhesion Molecule & $*$ \\
SPAM1-v2 & Zona Pellucida Binding Protein & $*$ \\
ZPBP & Outer Dense Fiber of Sperm Tails 1 & $*$ \\
ODF1 & Basic Charged, Y-linked, 2 & $*$ \\
BPY2/VCY2 & $*$ \\
\hline$*$ Ballantyne (unp &
\end{tabular}

* Ballantyne (unpublished)

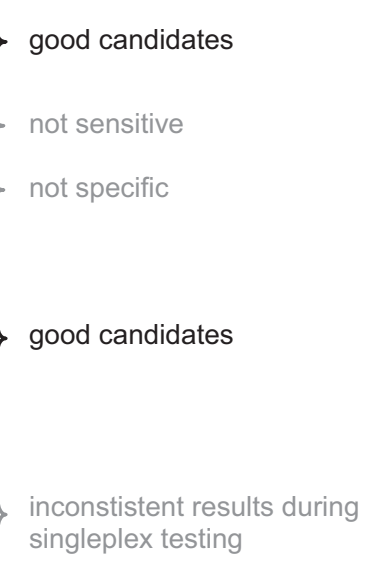

singleplex testing 
were asked, but not required, to examine additional samples: (1) bona fide or mock casework material that could include human and/or non-human saliva and semen stains; or (2) other forensically relevant body fluids (semen, saliva, vaginal secretions or menstrual blood).

HPLC-purified primers were purchased from Microsynth (St. Gallen, Switzerland) or Applied Biosystems (AB, Rotkreuz, Switzerland). The organizing laboratory prepared primer mixes for the multiplexes and aliquots were provided to the participating laboratories for use in amplification reactions (see below). In the second part, singleplex primers for HTN3, MUC7, PRM2 and SEMG1 were provided to permit a comparison of results obtained using singleplex and multiplex analysis. The primers and samples were sent by normal post (part 1, arrival within 2-4 days, except 2 parcels that were 7 and 11 days in transit) or by Fedex (part 2, arrival within 1-3 days, except 1 parcel that was 7 days in transit).

\subsection{Human tissue and animal samples}

Total RNA from 20 human tissues (adipose, bladder, brain, cervix, colon, esophagus, heart, kidney, liver, lung, ovary, placenta, prostate, skeletal muscle, small intestine, spleen, testes, thymus, thyroid and trachea) included in the FirstChoice ${ }^{\circledR}$ Human Total RNA Survey Panel was obtained from Applied Biosystems/Ambion. All tissues included in the panel were 3-donor pooled samples.

Buccal swabs and semen samples of domestic and exotic animals were collected by veterinary practitioners, zookeepers, a volunteer at an animal shelter, and/or owners (laboratories 9, 10 and 19). Although some samples were obtained from the same species, they were collected from different animals.

\section{3. $R N A(/ D N A$ co-)extraction and reverse transcription}

The participating laboratories were asked to use the entire swab or stain for extraction (RNA only or RNA/DNA co-extraction). The organizing laboratory provided an example protocol for extraction and reverse transcription. The laboratories could, however, use methods of their own choice. The example protocol was described previously $[29,30]$.

\subsection{RNA- and DNA-quantification}

Participating laboratories were asked to quantify RNA using one of the following methods: Quant-iT ${ }^{\mathrm{TM}}$ RiboGreen ${ }^{\circledR}$ RNA Assay kit (Invitrogen) using a fluorescence microplate reader (high and low range protocol option) [6]; Quant-i ${ }^{\mathrm{TM}}$ RNA assay kit (Invitrogen) using the Qubit fluorometer [21]; or Bioanalyzer (Agilent) [15]. Laboratories were able to quantify DNA using a quantification system of their own choice (Table S1, supplementary materials).

\subsection{Endpoint $P C R$}

The primer sets and amplicon lengths are shown in Table S2. An additional larger amplicon (152 bp) detected in saliva samples using the HTN3 primers corresponds to another histatin isoform (HTN1), which shows 95\% sequence identity to HTN3 [6,14]. For the animal sample testing, it was expected that many "negative" results would be obtained due to the deliberate design and use of putative human or primate specific primer sequences. In an attempt to ensure that a negative result was genuine and not due to an absence of high quality RNA in the extract itself, all animal samples were tested using a housekeeping gene (HKG) triplex (B2M, UBC and UCE).

In the first part of the exercise, the forward primers were $5^{\prime}$ labeled with the alternative dyes Yakima Yellow or ATTO550 (VIC ${ }^{\mathbb{R}}$ and $\mathrm{NED}^{\mathrm{TM}}$ analogs, respectively). The alternative dyes caused spectral issues such as pull-up in the other dyes due to the use of matrices generated with the commonly used dyes VIC ${ }^{\mathbb{R}}$ and NED ${ }^{\mathrm{TM}}$ (AB). This is not a problem as long as all markers in the multiplex are labeled with one dye. For the second part of the exercise, the forward primers were labeled with the commonly used dyes (semen: VIC, saliva: NED) so that the correct spectral calibration matrices could be applied. The HKG forward primers were 5'labeled with ATT0550.

The following amplification conditions were recommended: saliva and HKG triplex: the $25 \mu \mathrm{l}$ reaction mix contained $2 \mu \mathrm{l} \mathrm{cDNA}$, $2.5 \mu \mathrm{l}$ primer mix (see below), $12.5 \mu \mathrm{l} 2 \times$ Multiplex PCR Mastermix (Multiplex PCR kit, QIAGEN), $2.5 \mu \mathrm{l}$ Q-Solution (Multiplex PCR kit; QIAGEN); semen pentaplex: the $25 \mu$ l reaction mix contained $2 \mu \mathrm{l}$ cDNA, $2.5 \mu \mathrm{l}$ primer mix (see below), $1 \mathrm{mM}$ dNTPs $(\mathrm{AB}), 1 \times$ Buffer II (AB), $3.25 \mathrm{mM} \mathrm{MgCl}_{2}(\mathrm{AB})$, and $1.5 \mathrm{U}$ AmpliTaq ${ }^{\mathbb{}}$ Gold DNA Polymerase (AB); saliva and semen singleplexes: the $25 \mu \mathrm{l}$ reaction mix contained $2 \mu \mathrm{l}$ cDNA, $2 \mu \mathrm{l}$ primer mix (see below), $0.5 \mathrm{mM}$ dNTPs $(\mathrm{AB}), 1 \times$ Buffer I $(\mathrm{AB})$ and $1.25 \mathrm{U}$ AmpliTaq Gold ${ }^{\mathrm{B}}$ DNA Polymerase $(A B)$. Sterile water was used in place of cDNA for non-template controls.

The primer mixes were prepared using the following concentrations: saliva triplex: HTN3 $0.2 \mu \mathrm{M}$, STATH $0.4 \mu \mathrm{M}$, MUC7 $0.1 \mu \mathrm{M}$; semen pentaplex: PSA $0.72 \mu \mathrm{M}$, PRM2 $0.048 \mu \mathrm{M}$, SEMG1 $0.2 \mu \mathrm{M}$, TGM4 0.6 $\mu \mathrm{M}$, PRM1 $0.12 \mu \mathrm{M}$; saliva and semen singleplexes: $0.8 \mu \mathrm{M}$ each; HKG triplex: B2M $0.2 \mu \mathrm{M}$, UBC $0.2 \mu \mathrm{M}$, UCE $1 \mu \mathrm{M}$.

The cycling conditions were as follows: saliva triplex: the initial denaturation was at $95{ }^{\circ} \mathrm{C}$ for $15 \mathrm{~min}$, followed by 35 cycles of $94{ }^{\circ} \mathrm{C}$ $30 \mathrm{~s}, 57{ }^{\circ} \mathrm{C}\left(+0.2^{\circ} \mathrm{C}\right.$ per cycle) $90 \mathrm{~s}, 72{ }^{\circ} \mathrm{C} 60 \mathrm{~s}$ and the final elongation at $72{ }^{\circ} \mathrm{C}$ for $60 \mathrm{~min}$; semen pentaplex and saliva/semen singleplexes: the initial denaturation was at $95^{\circ} \mathrm{C}$ for $11 \mathrm{~min}$, followed by 35 cycles of $94{ }^{\circ} \mathrm{C} 20 \mathrm{~s}, 58{ }^{\circ} \mathrm{C} 30 \mathrm{~s}, 72{ }^{\circ} \mathrm{C} 40 \mathrm{~s}$ and the final elongation at $72{ }^{\circ} \mathrm{C}$ for $60 \mathrm{~min}$; HKG triplex: the initial denaturation was at $95{ }^{\circ} \mathrm{C}$ for $15 \mathrm{~min}$, followed by 35 cycles of $94{ }^{\circ} \mathrm{C}$ $30 \mathrm{~s}, 55{ }^{\circ} \mathrm{C}\left(+0.2^{\circ} \mathrm{C}\right.$ per cycle $) 90 \mathrm{~s}, 72{ }^{\circ} \mathrm{C} 40 \mathrm{~s}$ and the final elongation at $72^{\circ} \mathrm{C}$ for $30 \mathrm{~min}$.

Post PCR purification was recommended, particularly for the semen pentaplex, to eliminate dye blobs that could appear at marker specific positions (e.g. MinElute PCR purification kit, QIAGEN) [21,31].

\subsection{Capillary electrophoresis (CE)}

The participating laboratories used standard, multi-color fluorescent genetic analyzers and standard electrophoresis conditions for the detection of the saliva and semen specific amplicons (Table S1). Any dye set that included VIC ${ }^{\circledR}$ and $\mathrm{NED}^{\mathrm{TM}}$, with associated internal lane standard, could be used. Raw data were analyzed with Genemapper ${ }^{\mathbb{R}}$ Software $(A B)$. For data compilation, the threshold for a positive result was set to 100 RFUs (relative fluorescence units) for consistency between laboratories and to avoid inclusion of false positive results (due to the presence of dye blobs, baseline noise).

\subsection{DNA-amplification and-detection}

If DNA was co-extracted, the laboratories were able to use a standard STR typing kit, PCR and CE conditions of their choice (Table S1). A peak detection threshold of 50 RFUs was used.

\section{Results}

Laboratories 1-18 participated in part 1 of the exercise (stains 1-10 and dilution series A and B) and laboratories 1, 3-6, 8-13, 1520 participated in part 2 (stains $11-20$ and dilution series $C$ and $D$ ). Each laboratory was asked to complete a questionnaire describing 
the methods used (Table S1). The 20 laboratories used 5 different kits for RNA only or RNA/DNA co-extraction, 7 different reverse transcription kits, 7 different STR typing kits for DNA analysis, 5 different thermocyclers, 4 different genetic analyzers and 3 different polymers (Table S1).

The exercise was performed in 2 parts to allow for laboratories that encountered technical problems in part 1 to test additional samples once technical issues had been resolved (see Introduction). Laboratories that did not encounter technical challenges in part 1 were still encouraged to participate in part 2 of the exercise for comparison of the results from part 1 and for further evaluation of the included markers. From the experiences of part 1, various improvements were applied to part 2: (1) primers were labeled with common dyes to prevent pull-up into other spectra; (2) four RNA markers were provided additionally as singleplexes to permit comparisons of singleplex and multiplex analyses. Improved results could not be obtained in part 2 by laboratories 3,4 and 6 . These laboratories encountered non-identified technical problems, which were not attributable to the mRNA profiling method. Therefore, the results from these laboratories were excluded from the final data compilation. The data of laboratories 5 and 18 (part 1) and laboratory 19 (part 2) were excluded from the RNA results due to the use of a non-functional reverse transcriptase (lab 5) and the presence of RT minus contamination (labs 18 and 19). With the above mentioned laboratories excluded from data compilation, there was no significant difference in the results between parts 1 and 2 in terms of detectability and sensitivity of RNA markers and recoverability of STR profiles. Therefore, the results of parts 1 and 2 were combined in the tables and figures presented here.

\section{1. $R N A$ results}

The mRNA profiling results are summarized in Tables 2 and 3 . For exercise parts 1 and 2, thirteen laboratories (although not the same 13 laboratories in each part) were able to perform the method successfully as demonstrated by detection of the RNA saliva and semen markers. The 8 saliva and 6 semen stains were identified correctly by most laboratories (Table 2 ). Analysis of stain 11 ( $5 \mu \mathrm{l}$ saliva on paper) appeared to be challenging possibly due to the presence of inhibiting substances in the paper. Stains 4 and 12

Table 2

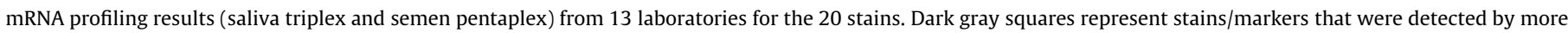

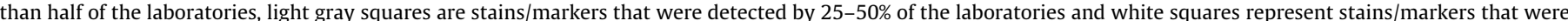

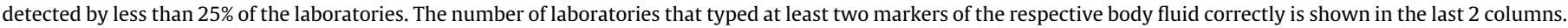

\begin{tabular}{|c|c|c|c|c|c|c|c|c|c|c|c|}
\hline \multirow[t]{2}{*}{ Sample } & \multirow[t]{2}{*}{ No. } & \multicolumn{3}{|c|}{ Saliva triplex } & \multicolumn{5}{|c|}{ Semen pentaplex } & \multicolumn{2}{|c|}{$>2$ markers positi } \\
\hline & & HTN3 & STATH & MUC7 & PSA & PRM2 & SEMG1 & TGM4 & PRM1 & Saliva & Semen \\
\hline 3 ul saliva on recycling tissue & 3 & $7 / 13$ & $4 / 13$ & $11 / 13$ & & & & & & $8 / 13$ & \\
\hline 1/4 chewed chewing gum & 6 & $6 / 13$ & $6 / 13$ & $9 / 13$ & & & & & & $7 / 13$ & \\
\hline $1 / 4$ buccal swab & 8 & $12 / 13$ & $12 / 13$ & $12 / 13$ & & & & & & $12 / 13$ & \\
\hline 5 ul saliva on pad & 10 & $11 / 13$ & $10 / 13$ & $12 / 13$ & & & & & & $12 / 13$ & \\
\hline 5 ul saliva on paper & 11 & $3 / 13$ & $4 / 13$ & $3 / 13$ & & & & & & $3 / 13$ & \\
\hline 5 ul saliva on glass slide & 14 & $9 / 13$ & $4 / 13$ & $6 / 13$ & & & & & & $6 / 13$ & \\
\hline 2 ul saliva on swab / 1 ul blood & 18 & $10 / 13$ & $9 / 13$ & $11 / 13$ & & & & & $1 / 13$ & $11 / 13$ & \\
\hline licked plastic spoon & 19 & $9 / 13$ & $5 / 13$ & $7 / 13$ & & & & & & $7 / 13$ & \\
\hline 5 ul saliva / 1 ul semen mix on swab & 5 & $13 / 13$ & $13 / 13$ & $13 / 13$ & $6 / 13$ & $13 / 13$ & $13 / 13$ & $10 / 13$ & $13 / 13$ & $13 / 13$ & $13 / 13$ \\
\hline 5 ul saliva / 1 ul semen mix on swab & 16 & $12 / 13$ & $12 / 13$ & $13 / 13$ & $8 / 13$ & $10 / 13$ & $12 / 13$ & $6 / 13$ & $10 / 13$ & $13 / 13$ & $12 / 13$ \\
\hline 2 ul semen on swab & 1 & & & $1 / 13$ & $8 / 13$ & $13 / 13$ & $13 / 13$ & $10 / 13$ & $13 / 13$ & & $13 / 13$ \\
\hline 3 ul semen on white textile & 9 & & & & $3 / 13$ & $10 / 13$ & $10 / 13$ & $4 / 13$ & $9 / 13$ & & $11 / 13$ \\
\hline $2 \mathrm{ul} \mathrm{semen}$ on toilet paper & 15 & & & & $4 / 13$ & $9 / 13$ & $8 / 13$ & $4 / 13$ & $9 / 13$ & & $9 / 13$ \\
\hline 3 ul semen inside latex glove & 20 & & & & $1 / 13$ & $9 / 13$ & $6 / 13$ & $3 / 13$ & $11 / 13$ & & $10 / 13$ \\
\hline $5 \mathrm{ul}$ azoospermic semen on swab & 4 & & & $1 / 13$ & $10 / 13$ & $3 / 13$ & $12 / 13$ & $11 / 13$ & $1 / 13$ & & $12 / 13$ \\
\hline 3 ul azoospermic semen on pad & 12 & & & & $10 / 13$ & $2 / 13$ & $11 / 13$ & $11 / 13$ & & & $11 / 13$ \\
\hline 3 ul human blood on swab & 2 & & & & & & & & & $13 / 13$ & $13 / 13$ \\
\hline 1/4 vaginal swab & 13 & & $1 / 13$ & $4 / 13$ & & & $1 / 13$ & & & $8 / 13$ & $12 / 13$ \\
\hline $1 / 4$ buccal swab (dog) & 7 & & $1 / 13$ & & & & & & & $12 / 13$ & $13 / 13$ \\
\hline $1 / 4$ buccal swab (cat) & 17 & $1 / 13$ & & & & $1 / 13$ & & & & $12 / 13$ & $12 / 13$ \\
\hline
\end{tabular}

Table 3

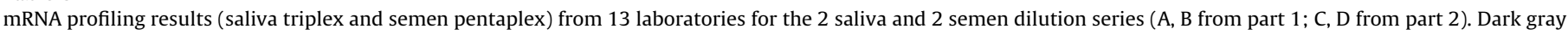

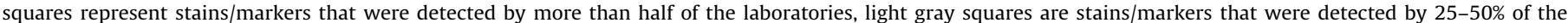
laboratories and white squares represent stains/markers that were detected by less than $25 \%$ of the laboratories.

saliva dilution series $B$ saliva dilution series $C$ semen dilution series A

\begin{tabular}{|r|c|c|c|}
\cline { 2 - 4 } \multicolumn{1}{c|}{10 ul } & HTN3 & STATH & MUC7 \\
\cline { 2 - 4 } 5 ul & $12 / 13$ & $11 / 13$ & $12 / 13$ \\
1 ul & $11 / 13$ & $10 / 13$ & $10 / 13$ \\
0.5 ul & $10 / 13$ & $5 / 13$ & $10 / 13$ \\
0.1 ul & $4 / 13$ & & $5 / 13$ \\
0.05 ul & $2 / 13$ & $1 / 13$ & $4 / 13$ \\
0.01 ul & $1 / 13$ & & \\
\hline
\end{tabular}

semen dilution series $\mathbf{D}$

\begin{tabular}{|c|c|c|c|c|}
\hline PSA & PRM2 & SEMG1 & TGM4 & PRM1 \\
\hline n.d. & n.d. & n.d. & n.d. & n.d. \\
\hline $11 / 13$ & $12 / 13$ & $12 / 13$ & $10 / 13$ & $12 / 13$ \\
$8 / 13$ & $11 / 13$ & $12 / 13$ & $6 / 13$ & $12 / 13$ \\
$6 / 13$ & $10 / 13$ & $11 / 13$ & $3 / 13$ & $10 / 13$ \\
$3 / 13$ & $6 / 13$ & $8 / 13$ & $1 / 13$ & $7 / 13$ \\
$5 / 13$ & $6 / 13$ & $2 / 13$ & $3 / 13$ & $3 / 13$ \\
$2 / 13$ & $3 / 13$ & $2 / 13$ & & $4 / 13$ \\
\hline
\end{tabular}

\begin{tabular}{|c|c|c|c|c|}
\hline PSA & PRM2 & SEMG1 & TGM4 & PRM1 \\
\hline n.d. & n.d. & n.d. & n.d. & n.d. \\
\hline $12 / 13$ & $13 / 13$ & $13 / 13$ & $13 / 13$ & $13 / 13$ \\
$12 / 13$ & $13 / 13$ & $12 / 13$ & $12 / 13$ & $13 / 13$ \\
$8 / 13$ & $11 / 13$ & $11 / 13$ & $12 / 13$ & $11 / 13$ \\
$1 / 13$ & $5 / 13$ & $2 / 13$ & $1 / 13$ & $8 / 13$ \\
$1 / 13$ & $6 / 13$ & $3 / 13$ & $2 / 13$ & $7 / 13$ \\
& & $1 / 13$ & & \\
\hline
\end{tabular}


were semen samples from azoospermic men and, therefore, no detection of PRM1 and PRM2 was expected. However, up to 3 laboratories detected one of these markers, which may be due to detection of residual sperm despite vasectomy. Two stains were saliva/semen mixtures (stains 5 and 16), both of which were identified as mixtures by all laboratories (Table 2). Four

\section{a}
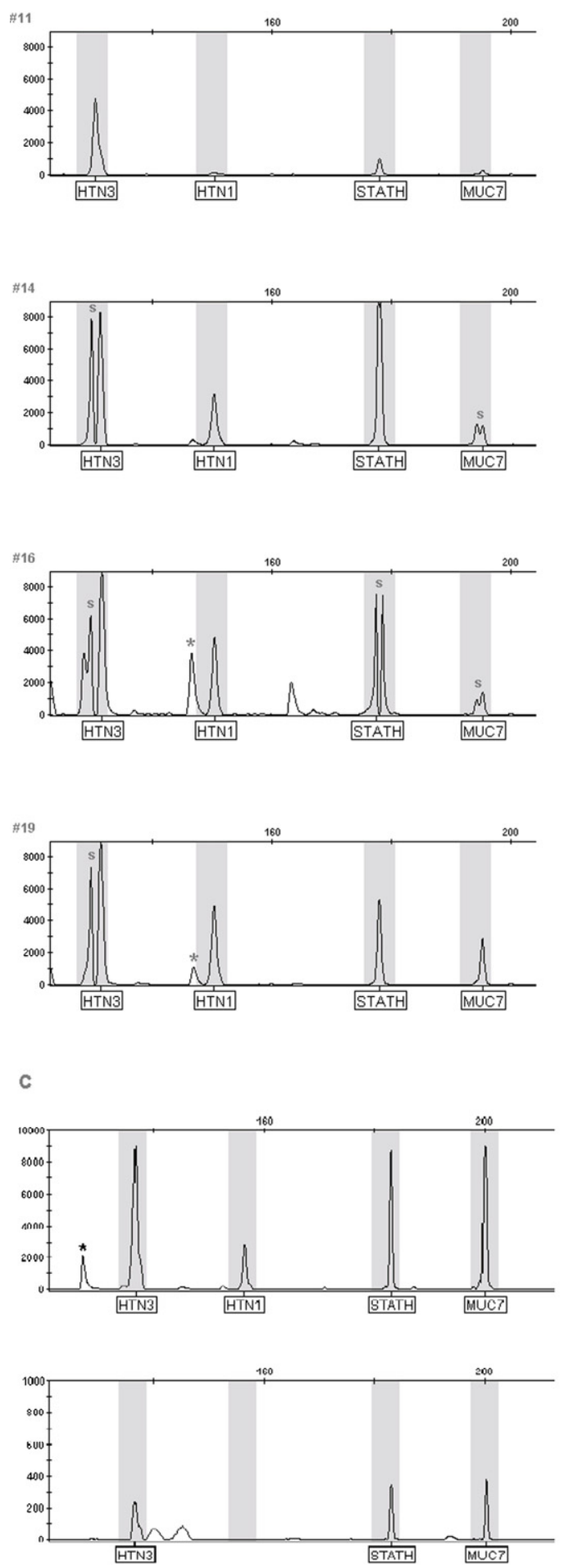

non-saliva/non-semen/non-human samples were included, and most laboratories (Table 2 ) obtained the expected result, which was the lack of any mRNA signal from the putative semen and saliva markers. However, sporadic single marker signals of unknown origin were obtained from the multiplex analysis by a small number of laboratories, mainly from the vaginal swab

\section{b}
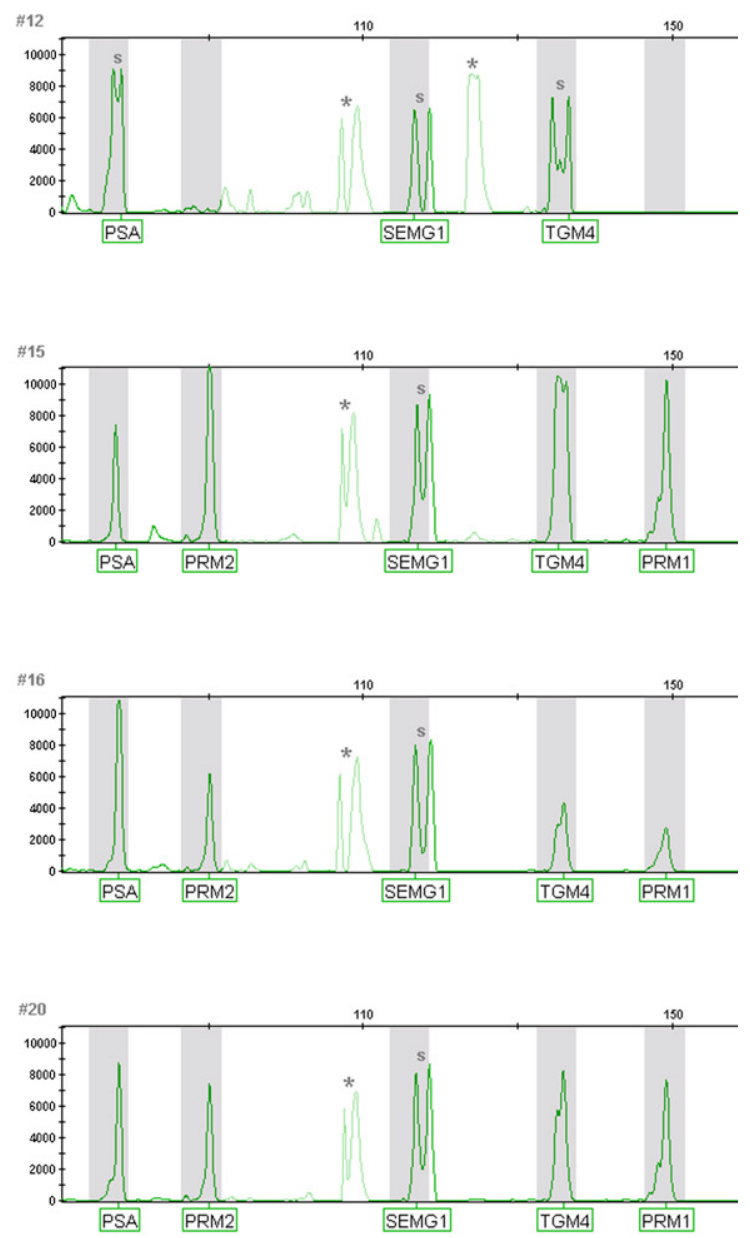

d
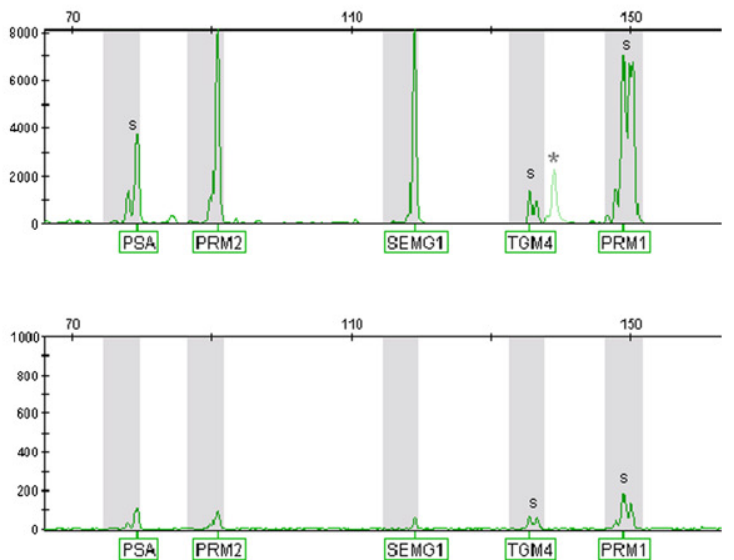

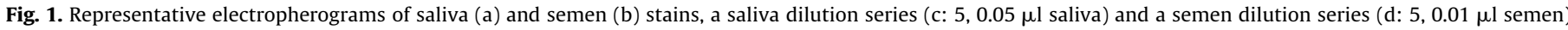

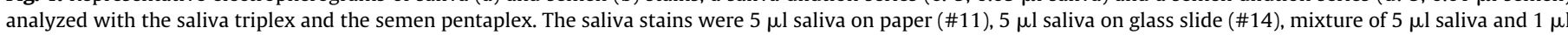

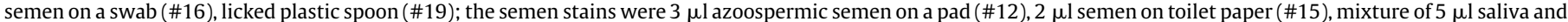

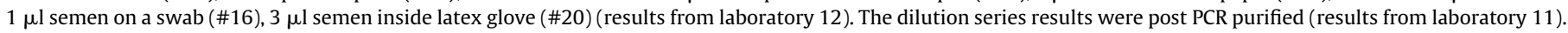
Some samples were saturated resulting in split peaks (s) and typical overflow peaks ( ${ }^{*}$, dimmed) around $10 \mathrm{bp}$ in front of the main peaks [21]. 
(Table 2). Representative electropherograms of saliva and semen stains are shown in Fig. 1a and b. HTN3, STATH and MUC7 were detected down to $0.5 \mu \mathrm{l}$ saliva by more than half of the laboratories. A small number of laboratories were able to detect the saliva markers in as little as $0.05 \mu \mathrm{l}$ saliva (Table 3 and Fig. 1c). The semen markers PSA, PRM2, SEMG1, TGM4 and PRM1 were detectable down to $0.5 \mu \mathrm{l}$ semen by more than half of the laboratories. A small number of laboratories detected the semen markers in as little as $0.01 \mu \mathrm{l}$ semen (Table 3 and Fig. $1 \mathrm{~d}$ ). In part 2, some markers were also tested as singleplexes on the stains and the dilution series. Since the differences between multiplex and singleplex testing were marginal, singleplex results are not shown nor discussed further.

No expression was detected for any of the markers in the RT minus (no reverse transcriptase added) or PCR negative controls by a majority of the laboratories. Laboratories 18 (only in part 1 , not in part 2) and 19 (participated only in part 2) observed expression in RT minus controls and were therefore not included in data compilation.

Only four laboratories quantified the RNA in part 1: two used the Quant-iT ${ }^{\mathrm{TM}}$ RNA assay kit, one used the Quant-iT ${ }^{\mathrm{TM}}$ RiboGreen ${ }^{\circledR}$ RNA Assay kit and one used the Bioanalyzer. Overall, the RNA quantification results were highly variable, probably because of the small stain sizes and the different quantification methods. Therefore, we did not attempt to determine the correlation (if any) between the quantification result and the RNA profiling success.

Post-PCR purification resulted in increased peak heights and reduced baseline signal noise but did not allow for detection of additional markers that were not observed prior to post-PCR purification. Post-PCR purification could be critical for the interpretation of the semen pentaplex results with dye blobs at marker-specific positions. Fifteen laboratories in part 1 and 11 laboratories in part 2 performed post-PCR purification.

\subsection{DNA results}

Fourteen and eleven laboratories (parts 1 and 2, respectively) performed RNA/DNA co-extraction. No specification of DNA analysis was provided. Various STR typing kits and cycle numbers were utilized by the participating laboratories (Table S1). Thus, as a result of the varying conditions used, direct sensitivity and success rate comparisons could not be made. However, the results demonstrated that DNA of sufficient quantity and quality for STR analysis can be simultaneously extracted with RNA from small amounts of dried saliva and semen (Table 4). Full STR profiles were obtained from all human donor stains by most laboratories (data not shown). The obtained genotypes were confirmed by comparison with the reference profiles. Full profiles were obtained from the saliva dilution series $C$ from $0.5 \mu \mathrm{l}$ saliva stains, whereas partial profiles were obtained down to $0.1 \mu \mathrm{l}$ saliva (Table 4 ). The quality of the STR typing results of saliva dilution series B was slightly lower, possibly resulting from donor-specific differences. From the semen dilution series A and D, full STR profiles were obtained from as little as $0.05 \mu \mathrm{l}$ semen stains, and partial STR profiles were obtained from $0.01 \mu$ l semen (Table 4 ).

\subsection{RNA and DNA results of the optional stain samples}

The laboratories were invited to analyze additional samples including bona fide and mock casework samples, non-saliva, nonsemen and non-human body fluid samples. Eighteen saliva stains and 18 semen stains were analyzed by 7 different laboratories. At least one of the specific markers was detectable in almost all saliva and semen stains, including various sizes, storage periods and storage conditions (Table 5). Representative RNA and DNA electropherograms are shown in Figs. S1 and S2. With saliva stains, only an outdoor saliva sample (covered, 7d) showed no result at all, probably due to degradation or absence of genetic material from exposure to outdoor conditions. Two of the semen stains were negative, probably because of low input amount, difficult starting material or questionable semen contribution.

Twenty-one non-saliva samples ( 4 blood, 6 semen, 8 vaginal swabs and 3 others) were analyzed with the saliva triplex by 8 laboratories. Five 'cross reactive' peaks (all <1000 RFUs) were observed, again mainly in vaginal swabs (Table 5). Twenty-one non-semen samples ( 4 blood, 8 saliva, 7 vaginal swabs and 2 others) were analyzed with the semen pentaplex by 8 laboratories. Only 1 'cross reactive' peak was observed (SEMG1 in a blood sample). Full autosomal STR profiles were obtained for most samples where an RNA/DNA co-extraction was performed (data not shown).

\section{Table 4}

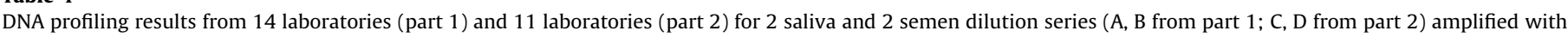

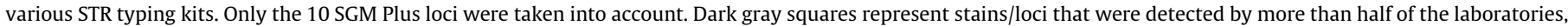

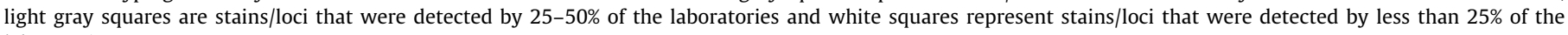
laboratories.

saliva dilution series $B$

\begin{tabular}{|r|c|c|c|c|c|c|c|c|c|c|c|}
\multicolumn{1}{c|}{10 ul } & \multicolumn{1}{c|}{ vWA } & D16 & D2 & AML & D8 & D21 & D18 & D19 & TH01 & FGA & D3 \\
\cline { 2 - 11 } & n.d. & n.d. & n.d. & n.d. & n.d. & n.d. & n.d. & n.d. & n.d. & n.d. & n.d. \\
5 ul & $13 / 14$ & $12 / 14$ & $12 / 14$ & $13 / 14$ & $13 / 14$ & $13 / 14$ & $12 / 14$ & $13 / 14$ & $13 / 14$ & $13 / 14$ & $13 / 14$ \\
1 ul & $10 / 14$ & $7 / 14$ & $6 / 14$ & $11 / 14$ & $9 / 14$ & $9 / 14$ & $6 / 14$ & $9 / 14$ & $11 / 14$ & $7 / 14$ & $8 / 14$ \\
0.5 ul & $8 / 14$ & $6 / 14$ & $2 / 14$ & $10 / 14$ & $6 / 14$ & $5 / 14$ & $5 / 14$ & $9 / 14$ & $10 / 14$ & $5 / 14$ & $6 / 14$ \\
0.1 ul & $1 / 14$ & & & $2 / 14$ & $1 / 14$ & $2 / 14$ & $1 / 14$ & & & & $2 / 14$ \\
0.05 ul & $1 / 14$ & $1 / 14$ & & $2 / 14$ & & & $1 / 14$ & $1 / 14$ & & & $1 / 14$ \\
0.01 ul & & & & $1 / 14$ & & & & & & & \\
\hline
\end{tabular}

semen dilution series $\mathrm{A}$

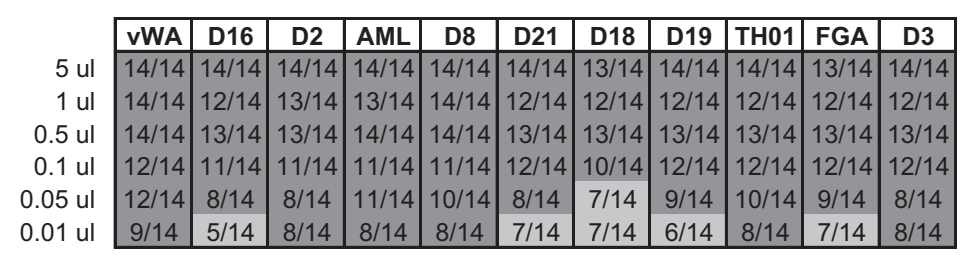

saliva dilution series $\mathbf{C}$

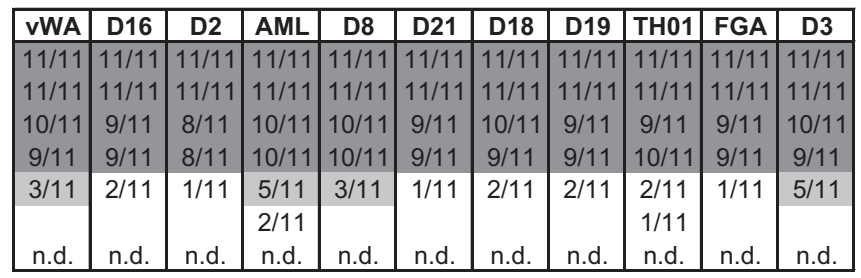

semen dilution series D

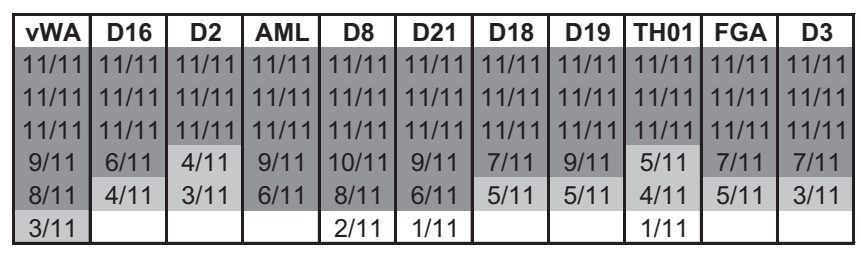


Table 5

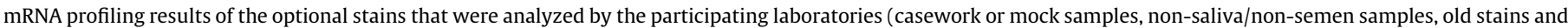
environmentally exposed stains). Numbers are peak heights in RFUs, light gray squares represent RNA peaks $<1000$ RFUs, dark gray squares $>1000$ RFUs.

additional saliva stains or non-saliva samples

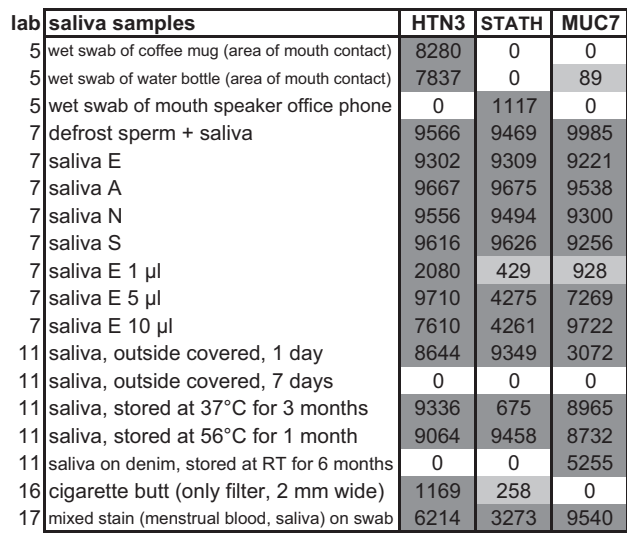

\begin{tabular}{|c|c|c|c|c|}
\hline lab & non-saliva samples & HTN3 & STATH & MUC7 \\
\hline 2 & $3 \mu \mathrm{l}$ blood on FTA & 0 & 0 & 0 \\
\hline 11 & $50 \mu \mathrm{l}$ blood on cotton & 0 & 0 & 0 \\
\hline 13 & $10 \mu \mathrm{l}$ blood on swab, stored at RT for 1 year & 0 & 0 & 0 \\
\hline 14 & blood & 0 & 0 & 0 \\
\hline 5 & $0.9 \mathrm{~cm} 2$ area from panties, sexual assault (PSA pos.) & 0 & 0 & 0 \\
\hline 7 & sperm on paper & 0 & 0 & 0 \\
\hline 7 & defrost sperm & 0 & 0 & 0 \\
\hline 16 & sperm in condom (1 $\mu \mathrm{l}$ 1:10 dil.) & 0 & 0 & 0 \\
\hline 16 & $1 \mu \mathrm{l}$ prostate secretion & 0 & 0 & 292 \\
\hline 17 & $5 \mu \mathrm{l}$ azoospermic semen stain, 2 years old & 0 & 0 & 0 \\
\hline 11 & $1 / 2$ vaginal swab & 0 & 0 & 0 \\
\hline 16 & vaginal swab & 0 & 0 & 0 \\
\hline 16 & vaginal swab + Sperm $(1 \mu \mathrm{l})$ & 0 & 0 & 0 \\
\hline 17 & vaginal swab TSI 4 days & 221 & 0 & 0 \\
\hline 17 & vaginal swab TSI $\geq 7$ days & 0 & 0 & 0 \\
\hline 17 & vaginal swab $T S I \geq 7$ days & 0 & 0 & 0 \\
\hline 17 & vaginal swab TSI 2 days & 0 & 0 & 550 \\
\hline 17 & vaginal swab TSI 2 days & 0 & 0 & 272 \\
\hline 11 & 1/2 menstrual swab & 0 & 0 & 0 \\
\hline 13 & mixed stain on fabric, stored at RT for 4 years & 0 & 0 & 0 \\
\hline 17 & mixed stain ( menstrual blood, semen) on swab & 0 & 624 & 0 \\
\hline
\end{tabular}

additional semen stains or non-semen samples

\begin{tabular}{|c|c|c|c|c|c|c|}
\hline & semen samples & PSA & PRM2 & SEMG1 & TGM4 & PRM1 \\
\hline & $0.9 \mathrm{~cm} 2$ area from panties, sexual assault (PSA pos.) & 1835 & 8899 & 6610 & 0 & 8231 \\
\hline 7 & sperm on paper & 0 & 0 & 2248 & 0 & 0 \\
\hline 7 & defrost sperm & 0 & 0 & 46 & 0 & 0 \\
\hline 7 & erm + saliva & 0 & 0 & 200 & 0 & 0 \\
\hline 9 & semen from human 3170 & 139 & 2221 & 3479 & 2677 & 8092 \\
\hline 9 & semen from human 3280 & 0 & 859 & 1079 & 523 & 3570 \\
\hline 9 & semen from human 5302 & 108 & 4846 & 1803 & 1487 & 7941 \\
\hline 11 & semen, outside covered, 1 day & 4689 & 8583 & 7493 & 5683 & 8236 \\
\hline 11 & semen, outside covered, 7 days & 0 & 0 & 0 & 0 & 0 \\
\hline 11 & semen stored at $37^{\circ} \mathrm{C}$ for 3 months & 7889 & 7837 & 8501 & 7486 & 7821 \\
\hline 11 & semen stored at $56^{\circ} \mathrm{C}$ for 1 month & 4589 & 8375 & 8266 & 6009 & 8289 \\
\hline 11 & semen on denim, stored at RT for 6 months & 0 & 8483 & 7412 & 5454 & 8502 \\
\hline 13 & mixed stain on fabric, stored at RT for 4 years & 9791 & 32199 & 20902 & 24514 & 31647 \\
\hline 16 & $1 \mu l$ prostate secretion & 6809 & 0 & 1369 & 7307 & 0 \\
\hline 16 & vaginal swab + sperm $(1 \mu \mathrm{l})$ & 0 & 0 & 0 & 0 & 0 \\
\hline 16 & sperm in condom (1 $\mu \mathrm{l}$ 1:10 dil.) & 1655 & 7885 & 8132 & 3616 & 7577 \\
\hline 17 & mixed stain (menstrual blood, semen) on swab & 551 & 7437 & 6532 & 1051 & 7377 \\
\hline & $5 \mu \mathrm{l}$ azoospermic semen stain, 2 years old & 1660 & 0 & 6617 & 1337 & 0 \\
\hline
\end{tabular}

\begin{tabular}{r|l|c|c|c|c|c|} 
Iab & non-semen samples & PSA & PRM2 & SEMG1 & TGM4 & PRM1 \\
2 & $3 \mu$ blood on FTA & 0 & 0 & 781 & 0 & 0 \\
11 & $50 \mu$ blood on cotton & 0 & 0 & 0 & 0 & 0 \\
13 & $10 \mu$ blood on swab, stored at RT for 1 year & 0 & 0 & 0 & 0 & 0 \\
14 & blood & 0 & 0 & 0 & 0 & 0 \\
5 & wet swab of coffee mug (area of mouth contact) & 0 & 0 & 0 & 0 & 0 \\
5 & wet swab of water bottle (area of mouth contact) & 0 & 0 & 0 & 0 & 0 \\
5 & wet swab of mouth speaker office phone & 0 & 0 & 0 & 0 & 0 \\
7 & saliva E & 0 & 0 & 0 & 0 & 0 \\
7 & saliva A & 0 & 0 & 0 & 0 & 0 \\
7 & saliva N & 0 & 0 & 0 & 0 & 0 \\
7 & saliva S & 0 & 0 & 0 & 0 & 0 \\
16 & cigarette butt (only filter, 2 mm wide) & 0 & 0 & 0 & 0 & 0 \\
11 & $1 / 2$ vaginal swab & 0 & 0 & 0 & 0 & 0 \\
16 & vaginal swab & 0 & 0 & 0 & 0 & 0 \\
17 & vaginal swab TSI 4 days & 0 & 0 & 0 & 0 & 0 \\
17 & vaginal swab TSI $\geq 7$ days & 0 & 0 & 0 & 0 & 0 \\
17 & vaginal swab TSI $\geq 7$ days & 0 & 0 & 0 & 0 & 0 \\
17 & vaginal swab TSI 2 days & 0 & 0 & 0 & 0 & 0 \\
17 & vaginal swab TSI 2 days & 0 & 0 & 0 & 0 & 0 \\
11 & $1 / 2$ menstrual swab & 0 & 0 & 0 & 0 & 0 \\
17 & mixed stain (menstrual blood, saliva) on swab & 0 & 0 & 0 & 0 & 0 \\
\hline
\end{tabular}

\subsection{Tissue- and species-specificity of the saliva and semen multiplexes}

The organizing laboratory (Zürich) tested the saliva and semen multiplexes on total RNA from a commercially available human tissue panel, including 20 human tissues (Table S3). The saliva triplex only showed positive signals with thyroid and trachea. The semen pentaplex showed reactions only with prostate and testes (Table S3).

Three laboratories (Brussels, Glasgow, Copenhagen) tested the saliva and semen multiplexes on animal saliva and semen samples. The only animal samples where species cross-reactivity was observed were gorilla saliva (HTN3, STATH and MUC7 (Table 6)) and chimpanzee semen (TGM4 (Table 7)). Most animal samples showed positive reactions with at least one of the housekeeping genes, confirming the presence of RNA in these samples.

\section{Discussion}

The purpose of this exercise was to evaluate an RNA/DNA coextraction strategy with challenging saliva and semen samples and two novel saliva- and semen-specific mRNA multiplexes (a saliva triplex with the saliva-specific markers HTN3, STATH and MUC7 as well as a semen pentaplex with the semen-specific markers PSA, PRM2, SEMG1, TGM4 and PRM1). The semen pentaplex permits the detection of both, sperm and seminal plasma, thereby allowing the identification of both spermic and azoospermic semen. Co-extracted DNA was analyzed with various commercial STR typing kits.

Most participating laboratories successfully applied the method using their own laboratory equipment and different kits and chemicals for RNA only or RNA/DNA co-extraction, reverse transcription and PCR. The samples to be analyzed in this exercise were challenging because the laboratories did not know the tissue origin and all stains were low template samples. The differing sensitivities between the laboratories can be explained by the different extraction kits and reverse transcription biochemicals and the skill sets within the laboratories, since those laboratories with more experience in RNA analysis in general produced better results than the others. The data from a small number of laboratories was excluded due to technical problems not attributable to the mRNA profiling method.

The evaluated saliva and semen markers proved to be specific and sensitive and therefore suitable for forensic stains, even aged and low template samples. "Specificity" in the context of gene expression and in reference to a specific body fluid can indicate either that expression of a particular gene is only observed in the body fluid of interest or can be used to describe markers whose expression is significantly higher in the body fluid of interest than in other body fluids. While the latter is perhaps more frequently observed and presents a greater challenge in terms of interpretation, proper interpretation guidelines could be developed to still permit 
Table 6

Saliva triplex results of animal saliva samples. In addition, the expression of 3 housekeeping genes (B2M, UBC, UCE) was analyzed to confirm successful analysis despite negative saliva results. Numbers are peak heights in RFUs, positive results ( $>100$ RFUs) are highlighted by shading.

\begin{tabular}{|c|c|c|c|c|c|c|c|}
\hline lab & Animal & HTN3 & STATH & MUC7 & B2M & UBC & UCE \\
\hline 10 & Bearded dragon & 0 & 0 & 0 & 0 & 0 & 0 \\
\hline 10 & Bull & 0 & 0 & 0 & 0 & 0 & 0 \\
\hline 10 & Cat & 0 & 0 & 0 & 0 & 0 & 1851 \\
\hline 9 & Cat & 0 & 0 & 0 & n.d. & n.d. & n.d. \\
\hline 10 & Chicken & 0 & 0 & 0 & 0 & 0 & 0 \\
\hline 10 & Chinese water dragon & 0 & 0 & 0 & 0 & 0 & 522 \\
\hline 9 & Cow & 0 & 0 & 0 & n.d. & n.d. & n.d. \\
\hline 10 & Degu & 0 & 0 & 0 & 0 & 0 & 2014 \\
\hline 10 & Dog & 0 & 0 & 0 & 0 & 0 & 0 \\
\hline 9 & Dog & 0 & 0 & 0 & n.d. & n.d. & n.d. \\
\hline 10 & Duck & 0 & 0 & 0 & 0 & 0 & 378 \\
\hline 10 & Gerbil & 0 & 0 & 0 & 0 & 0 & 0 \\
\hline 10 & Goat & 0 & 0 & 0 & 0 & 0 & 404 \\
\hline 10 & Gorilla & 9259 & 8890 & 454 & 9481 & 366 & 651 \\
\hline 10 & Guinea pig & 0 & 0 & 0 & 0 & 0 & 0 \\
\hline 10 & Horse & 0 & 0 & 0 & 0 & 0 & 0 \\
\hline 9 & Horse & 0 & 0 & 0 & n.d. & n.d. & n.d. \\
\hline 10 & Jackdaw & 0 & 0 & 0 & 0 & 0 & 1061 \\
\hline 10 & Leguan & 0 & 0 & 0 & 0 & 0 & 498 \\
\hline 10 & Miniature horse & 0 & 0 & 0 & 63 & 641 & 0 \\
\hline 10 & Pig & 0 & 0 & 0 & 0 & 0 & 4052 \\
\hline 10 & Pigeon & 0 & 0 & 0 & 0 & 0 & 7733 \\
\hline 10 & Rabbit & 0 & 0 & 0 & 0 & 0 & 0 \\
\hline 10 & Human & 7878 & 6405 & 7748 & 9331 & 4002 & 156 \\
\hline
\end{tabular}

n.d., not determined.

an accurate identification of the presence of a particular biological fluid. The purpose of this study was not to develop such guidelines (hopefully it will be the subject of future EDNAP studies once markers for all relevant body fluids have been evaluated), but to simply begin to critically evaluate the sensitivity and specificity of reported semen- and saliva-specific markers and to initially demonstrate their potential future implementation in forensic casework.

Table 7

Semen pentaplex results of animal semen samples. In addition, the expression of 3 housekeeping genes (B2M, UBC, UCE) was analyzed to confirm successful analysis despite negative semen results. Numbers are peak heights in RFUs, positive results ( $>100$ RFUs) are highlighted by shading, asterisks indicate saturation.

\begin{tabular}{r|l|ccccc|ccc|}
\cline { 2 - 8 } lab & Animal & PSA & PRM2 & SEMG1 & TGM4 & PRM1 & B2M & UBC & UCE \\
\hline 9 & Chimpanzee & 0 & 0 & 0 & 2527 & 0 & .d. & n.d. & n.d. \\
19 & Cow & 0 & 0 & 0 & 0 & 0 & 0 & 0 & 0 \\
19 & Deer & 0 & 0 & 0 & 0 & 0 & 0 & 0 & 1187 \\
9 & Dog & 0 & 0 & 0 & 0 & 0 & n.d. & n.d. & n.d. \\
19 & Dog 1 & 0 & 0 & 0 & 0 & 0 & 0 & 0 & 4151 \\
19 & Dog 2 & 0 & 0 & 0 & 0 & 0 & 0 & 0 & 0 \\
19 & Dog 3 & 0 & 0 & 0 & 0 & 0 & 541 & 0 & 3355 \\
19 & Goat 1 & 0 & 0 & 0 & 0 & 0 & 1627 & 0 & 0 \\
19 & Goat 2 & 0 & 0 & 0 & 0 & 0 & 3374 & 2650 & 0 \\
19 & Horse 1 & 0 & 0 & 0 & 0 & 0 & 0 & 0 & 1055 \\
19 & Horse 2 & 0 & 0 & 0 & 0 & 0 & 0 & 0 & 946 \\
19 & Horse 3 & 0 & 0 & 0 & 0 & 0 & $10,492^{*}$ & 5149 & 2535 \\
9 & Pig & 0 & 0 & 0 & 0 & 0 & n.d. & n.d. & n.d. \\
19 & Pig 1 & 0 & 0 & 0 & 0 & 0 & 0 & 0 & 0 \\
19 & Pig 2 & 0 & 0 & 0 & 0 & 0 & 106 & 0 & 0 \\
19 & Pig 3 & 0 & 0 & 0 & 0 & 0 & 0 & 0 & 0 \\
19 & Sheep 1 & 0 & 0 & 0 & 0 & 0 & 0 & 0 & 0 \\
19 & Sheep 2 & 0 & 0 & 0 & 0 & 0 & 0 & 0 & 0 \\
19 & Human & $8945^{*}$ & $8556^{*}$ & $9330^{*}$ & $9119^{*}$ & $8851^{*}$ & $10,331^{*}$ & $10,164^{*}$ & $10,470^{*}$ \\
\hline
\end{tabular}

n.d., not determined.
With the examined saliva and semen markers, single crossreactive peaks were observed in non-target body fluids. Most of them appeared only once and may be characterized as outliers. The only reproducible finding of putative cross reactivity was a MUC7 transcript in some vaginal samples. Mucins are high molecular weight glycosylated proteins that form a major part of a protective biofilm on the surface of epithelial cells, where they can provide a barrier to particulate matter and bind microorganisms. MUC4 was originally described as vaginal marker, but has been found to crossreact with saliva [16,24]. Therefore, some cross-reactivity of MUC7 in vaginal samples is not surprising, particularly because vaginal swabs normally contain large quantities of epithelial cells. Additionally, in this study many laboratories did not perform an RNA quantification prior to reverse transcription resulting in the input of likely increased amounts of RNA. Since some markers will have lower level expression in non-target body fluids, it is critical that suitable input RNA levels are utilized in order to reduce the occurrence of such cross reactivity. The use of RNA quantification prior to the reverse transcription reaction would allow for a standardization of the input of RNA into the reaction thus possible resulting in a reduction in the occurrence of such cross reactivity. However, it may be premature at this stage to make a definitive determination of whether MUC7 will have a role in the identification of saliva. It may be possible, for example, to use MUC7 in combination with other markers in order to develop an expression profile for saliva.

The multiplex PCR systems need some further optimization prior to routine use in casework analysis because of multiplex design issues (e.g. split peaks, noisy baseline). However, the multiplexes used in these initial studies were simply designed to permit more efficient analysis compared to singleplex reactions (reducing time and cost for participating laboratories) and therefore did not undergo a full developmental validation before their use in the study. As a result, some of these design issues are expected. The use of post-PCR purification improved the quality of the multiplex results (reduced appearance of split peaks, dye blobs, etc.) and increased peak heights from low level samples. Therefore, it is possible that post-PCR purification could be included as part of the standard protocol in order to resolve quality issues without requiring significant labor-intensive multiplex optimization experiments.

RNA quantification was performed by 4 laboratories, but the results were not consistent, probably because of the low template samples and/or insufficient sensitivity of the quantification methods. None of the suggested RNA quantification systems are ideal as they are not human-specific. The Bioanalyzer normally attests poor RNA quality and low RNA Integrity Numbers (RIN) with forensic samples [15]. One of the 4 laboratories used an RNA-carrier before RNA quantification which could have interfered with the results.

The saliva and semen multiplexes confirmed body fluid- and species-specificity when tested on human tissues and animal samples. Positive reactions of the saliva triplex with thyroid and trachea and the semen pentaplex with prostate and testes is not surprising, since these tissues are associated with the respective body fluids. Both multiplexes showed positive reactions with primate samples. Cross-reactivity with primate samples is not entirely unexpected due to the close evolutionary relatedness to humans, but the presence of primate biological material is not likely to be found in forensic cases.

HKG expression could not be shown for all animal samples to confirm successful analysis despite a negative body fluid result. The 3 housekeeping gene markers were designed for human use, but the sequences are very similar in mammals. Failure to detect HKG expression could therefore result from species specificity of the HKG primers, low input amount or the lack of suitable quality 
RNA. The results are consistent with the saliva and semen markers having a high degree of specificity for humans/primates.

The following negative controls were included in RNA analysis: (1) RT minus (no reverse transcriptase added) to identify possibly contaminating DNA (frequently a larger size than the expected RNA product) or the presence of pseudogenes (same size as RNA product); (2) amplification blank. Laboratories 18 and 19 encountered problems with negative controls and therefore their results were not used in this study. In the evaluated multiplexes, RT minus controls should be negative because of prudent primer-design and no known pseudogenes. Contamination could happen during PCR (e.g. contamination of the mastermix with template) or during $\mathrm{CE}$ (e.g. re-using sample septa or buffer septa, crosstalk or carryover [32]).

The possibility of co-extracting RNA and DNA from the same stain sample is an important advantage since the amount of sample is often limited in forensic casework. The quantity and quality of DNA from co-extracted samples seemed to be sufficient for both casework and environmentally exposed samples. From almost all stains, good quality DNA profiles and the positive identification of saliva and semen could be achieved; even stains exposed to un-controlled humidity and old stains could be identified correctly. The use of RNA/DNA co-extraction methods presents an interesting opportunity to evaluate possible quantitative relationships between DNA and RNA from the same sample. However, such an evaluation could not be performed in the present study since there was variation in the chemistries, instruments and protocols that were used by the various laboratories, particularly for DNA where any STR kit could be used (i.e. no standard conditions between laboratories). Additionally, many laboratories did not perform RNA quantification and the current RNA quantification systems that are available may be influenced by contaminating residual DNA or endogenous bacteria present in some fluids. Therefore, this study, as was originally intended, simply affirms that a co-extraction strategy can be successfully utilized to obtain RNA and STR profiling results from individual samples. Future evaluation and validation of such an approach could indeed determine if quantitative relationships between DNA and RNA can be made in order to assist in interpretation of results.

In summary, the results of this study support an RNA/DNA coextraction strategy allowing for positive identification of the tissue/fluid source of origin (saliva and semen) by mRNA profiling as well as a simultaneous identification of the body fluid donor by STR profiling. The evaluated 3 saliva and 5 semen markers proved to be robust, reproducible and sensitive. Co-extracted DNA from the same stain provided good-quality STR profiles. For future body fluid identification systems, multiplexes for the simultaneous identification of several body fluids and possibly tissues would be preferable. A subsequent EDNAP mRNA exercise will include an evaluation of mRNA markers for the identification of menstrual blood and housekeeping genes. The collective knowledge gained from this series of collaborative exercises is likely to facilitate the formulation of recommended practices and procedures for mRNA profiling for body fluid identification. A major task will be the interpretation of RNA results, especially of partial and mixed RNA profiles. This will be the subject of future EDNAP exercises, once all markers and possibly multiplexes have been evaluated.

\section{Acknowledgements}

Special thanks for support and technical assistance to C. Bouakaze ${ }^{c}$, G. Förster ${ }^{g}$, S. Graziano (Department of Therapeutic Research and Medicines Evaluation, Istituto Superiore di Sanità, Rome, Italy), D. Niederwieser ${ }^{\mathrm{o}}$, S.S. Tobe ${ }^{\mathrm{u}}$ and M. Vennemann ${ }^{\mathrm{u}}$. We are grateful to all volunteers who provided samples for this study. We also would like to thank I. Jennes (from "Vlaams Opvang
Centrum voor vogels en wilde dieren") and F. Vercammen (from "Zoo Antwerpen") for kindly providing saliva from exotic animals.

\section{Appendix A. Supplementary data}

Supplementary data associated with this article can be found, in the online version, at http://dx.doi.org/10.1016/j.fsigen.2012.10.011.

\section{References}

[1] M. Bauer, A. Kraus, D. Patzelt, Detection of epithelial cells in dried blood stains by reverse transcriptase-polymerase chain reaction, J. Forensic Sci. 44 (1999) 1232-1236.

[2] M. Bauer, D. Patzelt, Evaluation of mRNA markers for the identification of menstrual blood, J. Forensic Sci. 47 (2002) 1278-1282.

[3] M. Bauer, D. Patzelt, Protamine mRNA as molecular marker for spermatozoa in semen stains, Int. J. Legal Med. 117 (2003) 175-179.

[4] J. Juusola, J. Ballantyne, Messenger RNA profiling: a prototype method to supplant conventional methods for body fluid identification, Forensic Sci. Int. 135 (2003) 85-96.

[5] G. Ferri, C. Bini, S. Ceccardi, S. Pelotti, Successful identification of two years old menstrual blood stain by using MMP-11 shorter amplicons, J. Forensic Sci. 49 (2004) 1387

[6] J. Juusola, J. Ballantyne, Multiplex mRNA profiling for the identification of body fluids, Forensic Sci. Int. 152 (2005) 1-12.

[7] C. Nussbaumer, E. Gharehbaghi-Schnell, I. Korschineck, Messenger RNA profiling: a novel method for body fluid identification by real-time PCR, Forensic Sci. Int. 157 (2006) 181-186.

[8] R. Fang, C.F. Manohar, C. Shulse, M. Brevnov, A. Wong, O.V. Petrauskene, P. Brzoska, M.R. Furtado, Real-time PCR assays for the detection of tissue and body fluid specific mRNAs, Int. Congr. Ser. 1288 (2006) 685-687.

[9] T.L. Noreault-Conti, E. Buel, The use of real-time PCR for forensic stain identification, Promega, Profiles in DNA 10 (1) (2007) 3-5.

[10] J. Juusola, J. Ballantyne, mRNA profiling for body fluid identification by multiplex quantitative RT-PCR, J. Forensic Sci. 52 (2007) 1252-1262.

[11] M. Bauer, RNA in forensic science, Forensic Sci. Int. Genet. 1 (2007) 69-74.

[12] M. Bauer, D. Patzelt, Identification of menstrual blood by real time RT-PCR: technical improvements and the practical value of negative results, Forensic Sci. Int. 174 (2008) 54-58

[13] D. Zubakov, E. Hanekamp, M. Kokshoorn, W. van Ijcken, M. Kayser, Stable RNA markers for identification of blood and saliva stains from whole genome expression analysis of time-wise degraded samples, Int. J. Legal Med. 122 (2008) $135-142$.

[14] C. Haas, B. Klesser, C. Maake, W. Bär, A. Kratzer, mRNA profiling for body fluid identification by reverse transcription endpoint PCR and realtime PCR, Forensic Sci. Int. Genet. 3 (2009) 80-88.

[15] C. Haas, C. Muheim, A. Kratzer, W. Bär, C. Maake, mRNA profiling for the identification of sperm and seminal plasma, Forensic Sci. Int. Genet. Suppl. Ser. 2 (2009) 534-535.

[16] C. Cossu, U. Germann, A. Kratzer, W. Bär, C. Haas, How specific are the vaginal secretion markers HBD1 and MUC4? Forensic Sci. Int. Genet. Suppl. Ser. 2 (2009) 536-537.

[17] H. Nakanishi, A. Kido, T. Ohmori, A. Takada, M. Hara, N. Adachi, K. Saito, A novel method for the identification of saliva by detecting oral streptococci using PCR, Forensic Sci. Int. 183 (2009) 20-23.

[18] R.I. Fleming, S. Harbison, The development of a mRNA multiplex RT-PCR assay for the definitive identification of body fluids, Forensic Sci. Int. Genet. 4 (2010) 244-256.

[19] R.I. Fleming, S. Harbison, The use of bacteria for the identification of vaginal secretions, Forensic Sci. Int. Genet. 4 (2010) 311-315

[20] H. Nakanishi, T. Ohmori, M. Hara, A. Takada, H. Shojo, N. Adachi, K. Saito, A simple identification method of saliva by detecting Streptococcus salivarius using loopmediated isothermal amplification, J. Forensic Sci. 56 (2011) S158-S161.

[21] C. Haas, E. Hanson, A. Kratzer, W. Bär, J. Ballantyne, Selection of highly specific and sensitive mRNA biomarkers for the identification of blood, Forensic Sci. Int. Genet. 5 (2011) 449-458.

[22] J. Wobst, R. Banemann, I. Bastisch, RNA can do better - an improved strategy for RNA-based characterization of different body fluids and skin, Forensic Sci. Int Genet. Suppl. Ser. 3 (2011) e421-e422.

[23] M.L. Lennard Richard, K.A. Harper, R.L. Craig, A.J. Onorato, J.M. Robertson, J. Donfack, Evaluation of mRNA marker specificity for the identification of five human body fluids by capillary electrophoresis, Forensic Sci. Int. Genet. (2011), http://dx.doi.org/10.1016/j.fsigen.2011.09.007.

[24] G. Hadžić, A. Lukan, K. Drobnič, Practical value of the marker MUC4 for identification of vaginal secretion in penile swabs, Forensic Sci. Int. Genet. Suppl. Ser. 3 (2011) e222-e223.

[25] M. Bauer, S. Polzin, D. Patzelt, Quantification of RNA degradation by semiquantitative duplex and competitive RT-PCR: a possible indicator of the age of blood stains? Forensic Sci. Int. 138 (2003) 94-103.

[26] M. Setzer, J. Juusola, J. Ballantyne, Recovery and stability of RNA in vaginal swabs and blood, semen and saliva stains, J. Forensic Sci. 53 (2008) 296-305. 
[27] D. Zubakov, M. Kokshoorn, A. Kloosterman, M. Kayser, New markers for old stains: stable mRNA markers for blood and saliva identification from up to 16-year-old stains, Int. J. Legal Med. 123 (2009) 71-74.

[28] F. Kohlmeier, P.M. Schneider, Successful mRNA profiling of 23 years old blood stains, Forensic Sci. Int. Genet. 6 (2012) 274-276.

[29] C. Haas, E. Hanson, W. Bär, R. Banemann, A.M. Bento, A. Berti, E. Borges, C. Bouakaze, A. Carracedo, M. Carvalho, A. Choma, M. Dötsch, M. Durianciková, P. Hoff-Olsen, C. Hohoff, P. Johansen, P.A. Lindenbergh, B. Loddenkötter, B. Ludes, O Maroñas, N. Morling, H. Niederstätter, W. Parson, G. Patel, C. Popielarz, E. Salata P.M. Schneider, T. Sijen, B. Sviezená, L. Zatkalíková, J. Ballantyne, mRNA profiling for the identification of blood - results of a collaborative EDNAP exercise, Forensic Sci. Int. Genet. 5 (2011) 21-26.
[30] C. Haas, E. Hanson, M.J. Anjos, W. Bär, R. Banemann, A. Berti, E. Borges, C. Bouakaze, A. Carracedo, M. Carvalho, V. Castella, A. Choma, G. De Cock, M. Dötsch P. Hoff-Olsen, P. Johansen, F. Kohlmeier, P.A. Lindenbergh, B. Ludes, O. Maroñas, D. Moore, M.L. Morerod, N. Morling, H. Niederstätter, F. Noel, W. Parson, G. Patel, C. Popielarz, E. Salata, P.M. Schneider, T. Sijen, B. Sviežena, M. Turanská, L. Zatkalíková, J. Ballantyne, RNA/DNA co-analysis from blood stains - results of a second collaborative EDNAP exercise, Forensic Sci. Int. Genet. 6 (2012) 70-80.

[31] P.J. Smith, J. Ballantyne, Simplified low-copy-number DNA analysis by post-PCR purification, J. Forensic Sci. 52 (2007) 820-829.

[32] Maximizing the Performance of Capillary Electrophoresis Systems, Applied Biosystems, Forensic News, 2010 July. 